\title{
Enhancing Precursor Quality of Cu-In-S Ternary Thin Films by Applying More Appropriate Deposition Procedure
}

Hasan Yildirim

Bursa Uludag Universitesi

Ahmet Peksoz ( $\nabla$ peksoz@uludag.edu.tr)

Uludag University

\section{Research Article}

Keywords: Electrodeposition, CIS thin films, Energy band gap, Hall-Effect measurements

Posted Date: November 3rd, 2021

DOI: https://doi.org/10.21203/rs.3.rs-946352/v1

License: (c) (i) This work is licensed under a Creative Commons Attribution 4.0 International License.

Read Full License 


\title{
Enhancing precursor quality of $\mathrm{Cu}-\mathrm{In}-\mathrm{S}$ ternary thin films by applying more appropriate deposition procedure
}

\author{
H. Yildirim, A. Peksoz
}

Physics Department, Faculty of Arts and Sciences, Bursa Uludag University, Gorukle Campus, 16059 Bursa, Turkey

\begin{abstract}
Copper indium sulphur (CIS) thin films were electrochemically grown from an acidic aqueous solution including $10 \mathrm{mM} \mathrm{CuCl}_{2}, 10 \mathrm{mM} \mathrm{InCl}_{3}, 20 \mathrm{mM} \mathrm{Na} 2 \mathrm{~S}_{2} \mathrm{O}_{3}$ and $200 \mathrm{mM} \mathrm{LiCl}$. Deposition potential is determined by means of cyclic voltammetry analysis. The precursor CIS thin films are produced at $-1.10 \mathrm{~V}$ for $600 \mathrm{~s},-0.90 \mathrm{~V}$ for $300 \mathrm{~s}$ and a mixed potential of $-0.25 \mathrm{~V}$ for $150 \mathrm{~s}$ and $1.10 \mathrm{~V}$ for $150 \mathrm{~s}$. It is reported that surface morphology and film stoichiometry vary remarkably with the deposition parameters. SEM images show a variation in the grain shape, homogeneity and agglomeration due to the different $\mathrm{Cu} / \mathrm{In}$ ratio. The produced films have XRD peaks belonging to both $\mathrm{CIS}_{2}$ crystalline phase and $\mathrm{S}$ element. The produced CIS material at $-1.1 \mathrm{~V}$ has a band gap of $1.66 \mathrm{eV}$. The CIS thin film produced at $-0.9 \mathrm{~V}$ has three different band gaps such as $1.76,2.59$ and $2.85 \mathrm{eV}$. The CIS material produced by two steps has also three different band gaps between 1.59 and $2.74 \mathrm{eV}$. The CIS films are p-type, and resistivity and mobility data are in the range 6.56-8.61 $\Omega \mathrm{cm}$ and $8.68-22.2 \mathrm{~cm}^{2} / \mathrm{Vs}$, respectively. It is found that the acceptor concentration of CIS thin films varies between $2.48 \times 10^{17}$ and $1.06 \times 10^{18} \mathrm{~cm}^{-3}$. In summary, this study reports a procedure to produce high-quality precursor CIS thin films, highlighting a promising material to be used in heterostructure photovoltaic devices as a p-type absorber layer.
\end{abstract}

Keywords: Electrodeposition, CIS thin films, Energy band gap, Hall-Effect measurements

* Corresponding author: Prof.Dr. Ahmet Peksoz

Postal address: Solar Cell Laboratory, Physics Department, Sciences and Arts Faculty, Uludag 
University, 16059 Gorukle-Bursa, Turkey

Phone: +90 2242941713

Fax: +90224 2941899

e-mail: peksoz@uludag.edu.tr

\section{Introduction}

Copper Indium Sulphide $\left(\mathrm{CuInS} \mathrm{S}_{2}\right)$ is a member of I-III-VI $\mathrm{VI}_{2}$ ternary chalcopyrite semiconductors which are mostly used in solar sell applications due to their direct band structures (Tell et al. 1971). The CuInS $S_{2}$ materials have an optical energy band gap of $1.5 \mathrm{eV}$ and a high absorption coefficient of $10^{-5} \mathrm{~cm}^{-1}$ (Tell et al. 1971; Sun et al. 1978). CuInS 2 materials can be produced both $\mathrm{n}$ and p-type depending on the stoichiometry (Kazmerski et al. 1975). This property is desirable for homojunction production (Kazmerski and Sanborn, 1977). Different vacuum and non-vacuum methods have been applied to grow/deposition of $\mathrm{CuInS}_{2}$ (CIS) thin films such as solvothermal growth (Yue et al. 2015), thermal evaporation (Scheer et al. 1993), single/multiple source deposition (Kazmerski and Shieh, 1977), flash evaporation (Neumann et al. 1981), spray pyrolysis (Oja et al. 2005), RF magnetron sputtering (Forbes et al. 2003), chemical vapor deposition (Hwang et al. 1981), chemical deposition (Padam and Rao, 1986), electrodeposition (Bouima et al. 2019; Yukawa et al. 1996; Nakamura and Yamamoto, 1997; Broussillou et al. 2011; Bhattacharya et al. 1984; Nakamura and Yamamoto, 2003; Hodes et al. 1985; Herrero and Ortega 1990). Among these processes, electrodeposition steps forward in recent years because it meets the demand of low-cost production of photovoltaic industry by providing non-vacuum, low temperature and large area production.

Based on the literature, the production of CIS thin films by electrodeposition is mainly performed in two methods: 1) single bath/one-step electrodeposition of precursor CIS films followed by an annealing (Bouima et al. 2019; Yukawa et al. 1996; Nakamura and Yamamoto, 1997; Bhattacharya 
et al. 1984; Nakamura and Yamamoto, 2003), 2) electrodeposition of Cu-In bilayer precursors followed by annealing under hydrogen sulfide or sulfur atmosphere (Broussillou et al. 2011; Hodes et al. 1985; Herrero and Ortega 1990). Yukawa et al. (1996) have grown CIS thin films in an aqueous electrolyte containing $\mathrm{CuSO}_{4}, \mathrm{In}_{2}\left(\mathrm{SO}_{4}\right)_{3}$ and $\mathrm{Na}_{2} \mathrm{~S}_{2} \mathrm{O}_{3}$ via electrodeposition. They have presented well-crystallized films by annealing in vacuum at $673 \mathrm{~K}$ (Yukawa et al. 1996). They have also reported that the conduction type of produced CIS films has changed from p-type to ntype as the In concentration increases in deposition solutions (Yukawa et al. 1996). Nakamura and Yamamoto (2003) have presented that CIS-based solar cells prepared by sulfurization of electrodeposited $\mathrm{Cu}$-In precursors exhibit an efficiency of 1.3\% (Nakamura and Yamamoto, 2003). They have reported that the morphology of the precursors can be improved when the deposition solution is prepared without $\mathrm{HCl}$ (Nakamura and Yamamoto, 2003). In the study done by Herrero and Ortega (1990), CIS thin films were produced by annealing electrochemically deposited Cu-In alloys in $\mathrm{H}_{2} \mathrm{~S}$ atmosphere (Herrero and Ortega, 1990). They have investigated the effect of annealing temperature and deposition time on the crystal quality (Herrero and Ortega, 1990). They have reported that the best CIS crystalline films are obtained for the annealing temperature of 400 ${ }^{\circ} \mathrm{C}$ and $500{ }^{\circ} \mathrm{C}$ and $\mathrm{CuInS}_{2}$ phase is observed only for the films annealed for 60 min or longer (Herrero and Ortega, 1990). Broussillou et al. (2011) have presented $11 \%$ efficient $\mathrm{CuInS}_{2}$-based solar cells with an active area of $0.421 \mathrm{~cm}^{2}$ prepared by rapid thermal annealing (Broussillou et al. 2011). Bhattacharya et al. (1984) have produced CIS thin films on Ti substrates by electrodeposition from aqueous electrolytes of $\mathrm{CuCl}, \mathrm{InCl}_{3}$, thiourea, triethanolamine and ammonia (Bhattacharya et al. 1984). They have annealed the films in $\mathrm{Ar}$ and $\mathrm{H}_{2} \mathrm{~S}$ atmosphere (Bhattacharya et al. 1984). They have reported that deposited films have included both $\mathrm{CuInS}_{2}$ (mainly) and $\mathrm{CuIn}_{5} \mathrm{~S}_{8}$ phases (Bhattacharya et al. 1984). 
Production of high quality CIS thin films depends on the properties of the precursor films. Therefore, it is first necessary to deposit high quality precursors. In this sense, this study focuses on growing of $\mathrm{Cu}$-In-S ternary precursor thin films produced by electrodeposition technique. It is presented physical properties of CIS precursor thin films prepared by one-step and two-step electrodeposition methods in aqueous solutions at four different deposition potentials between $0.25 \mathrm{~V}$ and $-1.1 \mathrm{~V}$. The influences of deposition potential on the film stoichiometry, morphology and semiconductor properties are investigated.

\section{Experimental Details}

\subsection{Materials}

$\mathrm{CuCl}_{2}$ (99.99\%), $\mathrm{InCl}_{3}(99,99 \%), \mathrm{Na}_{2} \mathrm{~S}_{2} \mathrm{O}_{3}(99,99 \%)$ and $\mathrm{LiCl}(99.99 \%)$ were purchased from Sigma-Aldrich. Indium tin oxide (ITO) coated glass was used as substrate which has $0.5 \mathrm{~cm} \times 1$ $\mathrm{cm}$ surface area and $0-10 \Omega / \mathrm{cm}^{2}$ sheet resistance. All experiments were performed in aqueous solutions using ultra-pure water. Substrates were individually sonicated in acetone and then isopropanol for 5 minutes and rinsed with ultra-pure water and dried in air prior the deposition.

\subsection{Electrochemical Synthesis of Cu-In-S Ternary Materials}

$\mathrm{Cu}$-In-Se precursor thin films were electrochemically co-deposited on ITO substrates by a Gamry Reference 3000 Potentiostat/Galvanostat system. We used a three-electrode configuration in electrochemical cell. In this configuration, ITO substrate, platinum wire and saturated $\mathrm{Ag} / \mathrm{AgCl}$ correspond to working, counter and reference electrode, respectively. Deposition electrolyte includes $10 \mathrm{mM} \mathrm{CuCl}_{2}, 10 \mathrm{mM} \mathrm{InCl}_{3}, 20 \mathrm{mM} \mathrm{Na}_{2} \mathrm{~S}_{2} \mathrm{O}_{3}, 200 \mathrm{mM} \mathrm{LiCl}$, and $50 \mathrm{cc}$ ultra-pure water. Acidic solution medium was provided by adjusting $\mathrm{pH}$ of the electrolyte to $\sim 2.0$ with $\mathrm{HCl}$. 
Production of $\mathrm{Cu}$-In-S ternary compounds was performed by using chronoamperometry method. In this study, three different films were produced depending on the deposition time and potential, and they were called as Films 1, 2 and 3. Films 1 and 2 were produced by single-step, while Film 3 was prepared by two-step electrodeposition technique. Film 1 was co-electrodeposited at a constant deposition potential of $-1.10 \mathrm{~V}$ for 600 s. Film 2 was co-electrodeposited at a constant deposition potential of $-0.90 \mathrm{~V}$ for $300 \mathrm{~s}$. Film 3 was produced at $-0.25 \mathrm{~V}$ for $150 \mathrm{~s}$ and $-1.10 \mathrm{~V}$ for 150 s. Fig. 1 shows the chronoamperometry curves during the electrochemical synthesis of $\mathrm{Cu}-\mathrm{In}$ S precursor thin films. Determination of deposition potential is explained in Section 3.1. The current is near to $32 \mathrm{~mA}$ for the Film 1, while it is $0.37 \mathrm{~mA}$ for the Film 2 (Fig. 1). For the Film 3 , the current at $-0.25 \mathrm{~V}$ is near to zero, while it is near to 0.38 at $-1.10 \mathrm{~V}$. Therefore, it is noted that the applied deposition voltage of $-1.10 \mathrm{~V}$ has main role on the formation of $\mathrm{Cu}-\mathrm{In}-\mathrm{S}$ for the Film 3.

\subsection{Measurements}

A Gamry Reference 3000 Potentiostat/Galvanostat/ZRA was used in electrodeposition of CIS precursor thin films. PHE200 Physical Electrochemistry software was used to carry out deposition experiments. The morphology of the films was characterized using Carl Zeiss Evo 40-type scanning electron microscope (SEM). Elemental composition of the films was investigated via Bruker AXS Microanalysis energy dispersive X-ray (EDX) analysis. Optical characterization experiments were conducted by Shimadzu-SolidSpec-2700 UV-VIS-NIR spectrophotometer. XRD studies were performed by using Bruker X-ray diffractometer D8 advance model. HMS-3000 Manual Ver. 3.5.1 Hall-Effect measurement system was used to determine the electrical properties 
of the CIS materials. Thickness measurements of the precursor thin films were carried out by an optical profilometer (Zeta- 20, Zeta Instruments, United States).

\section{Results and Discussion}

\subsection{Determination of Electrodeposition Process}

We try to explain the electrochemical mechanisms of the formation of $\mathrm{Cu}-\mathrm{In}-\mathrm{S}$ ternary thin films by means of cyclic voltammograms $(\mathrm{CV})$ belonging to the individual $\mathrm{Cu}$, In and Te constituents, and $\mathrm{Cu}$-In-Te ternary system. In our early work [21], we have reported individual cyclic voltammograms of $10 \mathrm{mM} \mathrm{CuCl}$ and $20 \mathrm{mM} \mathrm{Na} 2 \mathrm{~S}_{2} \mathrm{O}_{3}$ aqueous solutions. For this reason, the cyclic voltammograms of $\mathrm{Cu}$ and $\mathrm{S}$ molecular sources are not given in this study due to the avoiding repetition. The reduction peak of $\mathrm{Cu}^{2+}$ to $\mathrm{Cu}$ is reported at $-0.35 \mathrm{~V}$ vs $\mathrm{Ag} / \mathrm{AgCl}$ electrode, and deposition reaction can be given as (Yildirim and Peksoz, 2017):

$$
C u^{2+}+2 e^{-} \rightarrow C, \quad E^{0}=-0.35 V
$$

The reduction peak of $\mathrm{S}$ to $\mathrm{S}^{-2}$ is reported at $-0.90 \mathrm{~V}$ vs $\mathrm{Ag} / \mathrm{AgCl}$ electrode, and the peak can be explained by the following reaction (Yildirim and Peksoz, 2017):

$$
S+2 e^{-} \rightarrow S^{-2}, \quad E^{0}=-0.90 \mathrm{~V}
$$

The cyclic voltammogram of an aqueous electrolyte with $10 \mathrm{mM} \mathrm{InCl}_{3}$ and $200 \mathrm{mM} \mathrm{LiCl}$ is recorded in a potential interval from $-2 \mathrm{~V}$ to $-0.25 \mathrm{~V}$ with a scan step of $20 \mathrm{mV} / \mathrm{s}$ (Fig $2 \mathrm{a}$ ). Two cathodic peaks are observed at $-0.96 \mathrm{~V}$ and $-1.32 \mathrm{~V}$ (Fig 2a). The first peak is attributed to the reduction of $\mathrm{In}^{3+}$ to $\mathrm{In}$, and it can be described by the following reaction:

$$
I n^{3+}+3 e^{-} \rightarrow \text { In }, \quad E^{0}=-0.96 V
$$


The second peak at $-1.32 \mathrm{~V}$ is due to the evaluation of $\mathrm{H}_{2}$ gases (Fig. 2b). Fig $2 \mathrm{~b}$ shows cyclic voltammogram of an aqueous solution consisting of $10 \mathrm{mM} \mathrm{CuCl}_{2}, 10 \mathrm{mM} \mathrm{InCl}_{3}, 20 \mathrm{mM} \mathrm{Na}_{2} \mathrm{~S}_{2} \mathrm{O}_{3}$ and $200 \mathrm{mM} \mathrm{LiCl}$. The $\mathrm{pH}$ of solution is kept at $\sim 2$ using $\mathrm{HCl}$. Two cathodic peaks are observed at $-0.25 \mathrm{~V}$ and $-1.22 \mathrm{~V}$ vs. $\mathrm{Ag} / \mathrm{AgCl}$ reference (Fig. 2b). The peak at $-0.25 \mathrm{~V}$ is due to the changing of $\mathrm{S}_{2} \mathrm{O}_{3}^{2-}$ ions in acidic solutions to $\mathrm{S}$ and of $\mathrm{HSO}_{3}^{-}$according to the following reaction (Broussillou et al. 2011):

$$
\mathrm{S}_{2} \mathrm{O}_{3}^{2-}+\mathrm{H}^{+} \rightarrow \mathrm{S}+\mathrm{HSO}_{3}^{-}
$$

The peak at $-1.22 \mathrm{~V}$ is attributed to the formation of $\mathrm{Cu}-\mathrm{In}-\mathrm{S}$ ternary structure by the following reaction:

$$
x C u+y \operatorname{In}+z S \rightarrow C u_{x} I_{y} S_{z}
$$

It is noted that formation of CIS compound moves towards more negative potentials compared with individual deposition of $\mathrm{Cu}$, In and $\mathrm{S}$ constituents (Fig. 2b). The formation of CIS compound starts at $-0.85 \mathrm{~V}$, reaches to maximum at $-1.22 \mathrm{~V}$, and finishes at $-1.35 \mathrm{~V}$ (Fig. 2b). According to the $\mathrm{CV}$ studies, the selection of an appropriate deposition potential should be within this potential interval. Therefore, two constant potentials such as $-0.90 \mathrm{~V}$ and $-1.10 \mathrm{~V}$ were applied to obtain CIS compound. Afterwards, we want to test film production at the mixed potential of $-0.25 \mathrm{~V}$ and -1.10 $\mathrm{V}$, which are seen $\mathrm{CV}$ plot of the electrolyte including of $\mathrm{Cu}$, In and $\mathrm{S}$ molecular sources.

\subsection{Structural Studies}

SEM images of the produced CIS thin films are shown in Fig. 3. Bean-shaped grains are seen on the surface of Film 1 (Fig. 3a). Film 2 has spherical grains, and distribution of these grains is 
homogeneous (Fig. 3b). Size and shape of the grains on the surface of the Film 3 are irregular, and some aggregated formations and pores are seen on the surface (Fig. 3c). EDX data of the produced CIS materials are recorded from the whole surface seen in Fig. 3, and atomic percentages are listed in Table 1. The ratio of $[\mathrm{Cu}+\mathrm{In}] / \mathrm{S}$ is $1.71,1.34$ and 1.13 for the Films 1, 2 and 3, respectively (Table 1)

XRD patterns of the produced CIS thin films are shown in Fig. 4. According to the XRD studies of the produced films, the peaks observed at $2 \theta=21.44^{\circ}, 30.40^{\circ}, 35.34^{\circ}, 40.09,50.74^{\circ}$ and $60.46^{\circ}$ belong to the ITO substrate (Fig. 4). Grindle et al. (1979) have calculated XRD parameters by considering $\mathrm{CuInS}_{2}$ to be a chalcopyrite crystal phase with $\mathrm{a}=5.51 \AA$ and $\mathrm{c}=11.05 \AA$, and they have also supported these calculations with experimental observations (Grindle et al. 1979). Some of the peaks observed in our study are well matched with the XRD data given in the work done by Grindle et al. (1979). Film 1 has three weak peaks at $2 \theta=38.68^{\circ}, 45.52^{\circ}$ and $69.64^{\circ}$, which can be attributed to $\left(\begin{array}{lll}2 & 1 & 1\end{array}\right),\left(\begin{array}{lll}2 & 1 & 3\end{array}\right) /\left(\begin{array}{lll}1 & 0 & 5\end{array}\right)$ and $\left(\begin{array}{lll}4 & 0 & 0\end{array}\right) /\left(\begin{array}{lll}0 & 0 & 8\end{array}\right)$ due to the $\mathrm{CuInS}_{2}$ crystalline phase, respectively (Fig.4a) (Grindle et al. 1979). Film2 and Film 3 have a strong peak at $2 \theta=31.82^{\circ}$ and two small peaks at $2 \theta=37.52^{\circ}$ and $45.42^{\circ}$, which are identified as $\mathrm{CuInS}_{2}$ crystalline phase with $\left(\begin{array}{lll}2 & 0 & 0\end{array}\right) /\left(\begin{array}{lll}0 & 0\end{array}\right.$ 4), (2 11 1), and (2 113 )/(1 0 5 ), respectively (Fig. 4b and 4c) (Grindle et al. 1979). According to the JCPDS (Joint Committee on Powder Diffraction Standards) card no PDF 01-089-6764, the produced films have a peak at $2 \theta=22.40^{\circ}$ due to the triclinic lattice of Sulphur atoms. The crystallite size (D) of the precursor CIS materials is estimated by the Scherrer's equation given as (Vadivel et al. 2013):

$$
D=\frac{0.9 \lambda}{F W H M x \cos \theta}
$$


Where $\lambda$ is the wavelength of the X-rays used in the measurement (1.54056 $\AA$ ), $\theta$ and FWHM correspond to the diffraction angle and the full width at a half maximum intensity of the related peak, respectively. Crystallite size values are calculated for each XRD peak via Eq. (6), and the obtained data are listed in Table 2. Crystallite size belonging to $\mathrm{CIS}_{2}$ phase changes between 16 and 27 nm, 7 and 45 nm, and 14 and 29 nm for Film 1, Film 2 and Film 3, respectively (Table 2). Film 1 has two XRD peaks due to the sulphur element (Fig. 4a), while Film 2 and 3 have only a sulphur peak (Fig. 4b and 4c). Crystallite size of sulphur element is $16-21 \mathrm{~nm}, 4$ and $17 \mathrm{~nm}$ for Film 1, 2 and 3, respectively (Table 2). Crystallite size of the main $\mathrm{CIS}_{2}$ phase at $2 \theta=38.68^{\circ}$ is 27 , 7 and $19 \mathrm{~nm}$ for Film 1, 2, and 3, respectively. The crystallite size variation of this main CIS $_{2}$ phase with the biggest intensity is most probably due to the variation of indium percentage (Tables 1 and 2).

\subsection{Optical and Electrical Properties}

The physical thicknesses of the precursor CIS films are determined as $162 \mathrm{~nm}, 140 \mathrm{~nm}$ and $108 \mathrm{~nm}$ for Films 1, 2 and 3 respectively. Fig. 5a shows the absorbance spectra of the produced films in the range of $200 \mathrm{~nm}-1100 \mathrm{~nm}$. To calculate energy band gap $\left(\mathrm{E}_{\mathrm{g}}\right)$ of the films, absorbance data of the precursors are used in Tauc equation (Tauc et al. 1966),

$\alpha h v=\beta\left(h v-E_{g}\right)^{n}$

Where $\alpha$ is the absorption coefficient, $h v$ is the incident photon energy, $\beta$ is edge parameter, $n$ is a constant which takes the value $1 / 2$ for direct transitions and 2 for indirect transitions. Here $n$ is $1 / 2$ since CIS material has a direct band gap. The absorption coefficient $\alpha$ is calculated for each thin film using Beer-Lambert's equation: 
$\alpha=2.303 \frac{A}{d}$

Where $\mathrm{A}$ is the absorbance of the films for a given wavelength and $\mathrm{d}$ is the thickness of the thin film. The $E_{\mathrm{g}}$ values of the CIS thin films were determined from where the extended linear part of the $(\alpha h v)^{2}-h v$ curves hits the hv-axis (Fig 5b-d). While the $\mathrm{E}_{\mathrm{g}}$ of the Film 1 is $1.66 \mathrm{eV}$, Film 2 and Film 3 have three different band-gap values that may be caused by different ternary or single crystal phases of $\mathrm{Cu}-\mathrm{In}-\mathrm{S}$ system involved in mentioned precursor thin films. The formation of $\mathrm{E}_{\mathrm{g} 2}$ and $\mathrm{E}_{\mathrm{g} 3}$ energy band gaps for the Films 2 and 3 is attributed to transitions from a copper valance band to conduction band edge. $E_{g 1}$ values can be explained by film stoichiometry (Table 1). Herein, Eg1 values are 1.66, 1.76 and $1.59 \mathrm{eV}$ for Films 1, 2, and 3, respectively. $\mathrm{E}_{\mathrm{g} 1}$ energy band gap varies proportionally with the compositional ratio of $\mathrm{S} / \mathrm{Cu}$ ratio in the CIS films.

Conduction types of the electrodeposited precursor CIS films were measured by four probe HallEffect system. Some of the electrical parameters of the produced films are given in Table 3. All films show p-type conductivity. Hodes et al. (1984) have reported that if $\mathrm{Cu} / \mathrm{In}$ is greater than 1 in the films, the conductivity of the film is p-type, and if the $\mathrm{Cu} / \mathrm{In}$ is less than 1 then the conductivity of the film is n-type. Furthermore, Grindle et al. (1979) have reported that CIS films with excess sulphur exhibite p-type conductivity. The results reported by Grindle et al. (1979) support our results. However, the results in the present work are in conflict with those of Hodes et al. (1979). Some earlier literature summarization related with the structural, optical and electrical parameters of CIS ternary thin films is given in Table 4 . The acceptor density is between $2.48 \times 10^{17}$ and $1.06 \times 10^{18} \mathrm{~cm}^{-3}$ (Table 3), which are in accordance with the literature as seen in Table 4. The mobility increases from 8.68 to $22.2 \mathrm{~cm}^{2} / \mathrm{Vs}$, as the [Cu+In]/S ratio decreases from 1.71 to 1.13 (Table 1 and 3). The obtained mobility values in this study are higher than those of the literature (Table 4). 


\section{Conclusions}

The structural and electrical properties of the electrodeposited $\mathrm{Cu}$-In-Se thin films are reported. The $\mathrm{CV}$ studies show that individual deposition of $\mathrm{Cu}$, In and $\mathrm{S}$ elements on ITO substrate occurs at $-0.35,-0.96$ and $-0.90 \mathrm{~V}$, while electrodeposition of ternary CIS compound takes place at two deposition voltages such as -0.25 and $-1.22 \mathrm{~V}$ vs. $\mathrm{Ag} / \mathrm{AgCl}$. According to the mentioned $\mathrm{CV}$ behavior, three different CIS materials are prepared, and called as Films 1, 2 and 3. The precursor $\mathrm{Cu}-\mathrm{In}-\mathrm{S}$ ternary thin films have polycrystalline structure. Films 2 and 3 show three optical band gaps most likely due to their polycrystalline structures. However, Film 1 has an optical band gap of $1.66 \mathrm{eV}$ in spite of the fact that its polycrystalline nature. Optical band gap increases from 1.59 to $1.76 \mathrm{eV}$ with increasing $\mathrm{Cu} / \mathrm{In}$ ratio. Stoichiometry of Films 1,2 and 3 is $\mathrm{CuIn}_{18.1} \mathrm{~S}_{11.2}$, $\mathrm{CuIn}_{2.62} \mathrm{~S}_{2.70}$ and $\mathrm{CuIn}_{6.71} \mathrm{~S}_{6.83}$, respectively. Films 1,2 and 3 have a conductivity of $0.14,0.12$ and $0.151 / \Omega \mathrm{cm}$, respectively. The produced CIS materials exhibit p-type conductivity with the acceptor concentration range $\sim 10^{17}-10^{18} \mathrm{~cm}^{-3}$, which are well correlated with the literature data.

\section{References}

[1] Tell, B., Shay, J.L., Kasper, H.M.: Electrical Properties, optical properties, and band structure of $\mathrm{CuGaS}_{2}$ and CulnS $\mathrm{S}_{2}$. J. Physical Review B. 4 (1971) 2463-2471. https://doi.org/10.1103/PhysRevB.4.2463

[2] Sun, L.Y., Kazmerski, L.L., Clark, A.H., Ireland, P.J., Morton, D.W.: Absorption coefficient measurements for vacuum-deposited Cu-ternary thin films. J. Vac. Sci. Technol. 15 (1978) 265-268. https://doi.org/10.1116/1.569567. 
[3] Kazmerski, L.L., Ayyagari, M.S., Sanborn G.A.: CuInS 2 thin films: Preparation and properties. Journal of Applied Physics. 46 (1975) 4865-4869. https://doi.org/10.1063/1.321521.

[4] Kazmerski, L.L., Sanborn G.A.: $\mathrm{CuInS}_{2}$ thin-film homojunction solar cells. Journal of Applied Physics. 48 (1977) 3178-3180. https://doi.org/10.1063/1.324058.

[5] Yue, W., Pan, Y., Xie, Z., Yang, X., Hu, L., Hong, L., Tong, Y., Cheng, Q.: Different depositing amount of $\mathrm{CuInS}_{2}$ on $\mathrm{TiO}_{2}$ nanoarrays for polymer/CuInS $\mathrm{S}_{2}-\mathrm{TiO}_{2}$ solar cells. Materials Science in Semiconductor Processing. 40 (2015) 257-261. https://doi.org/10.1016/j.mssp.2015.06.072.

[6] Scheer, R., Walter, T., Schock, H.W., Fearheiley, M.L., Lewerenz, H.J.: CuInS 2 based thin film solar cell with 10.2\% efficiency. Applied Physics Letters. 63 (1993) 3294-3296. https://doi.org/10.1063/1.110786.

[7] Kazmerski, L.L., Shieh, C.C.: Photoconductivity effects in $\mathrm{CuInS}_{2}, \mathrm{CuInSe}_{2}$ and $\mathrm{CuInTe}_{2}$ thin films, Thin Solid Films. 41 (1977) 35-41. https://doi.org/10.1016/00406090(77)90007-4.

[8] Neumann, H., Hörig, W., Savelev, V., Lagzdonis, J., Schumann, B., Kühn, G.: The optical properties of CuInS 2 thin films. Thin Solid Films. 79 (1981) 167-171. https://doi.org/10.1016/0040-6090(81)90275-3.

[9] Oja, L., Nanu, M., Katerski, A., Krunks, M., Mere, A., Raudoja, J., Goossens, A.: Crystal quality studies of $\mathrm{CuInS}_{2}$ films prepared by spray pyrolysis, Thin Solid Films. 480-481 (2005) 82-86. https://doi.org/10.1016/j.tsf.2004.11.013. 
[10] Forbes, I., Reddy, K.T.R., Johnson, D., Miles, R.W., Lane, D.W., Rogers, K.D., Chapman A.: R.f. sputtering of high-quality $\mathrm{Cu} / \mathrm{In}$ precursor layers and conversion to $\mathrm{CuInS}_{2}$ using elemental sulfidization processes. Journal of Materials Science: Materials in Electronics. 14 (2003) 567-571. https://doi.org/10.1023/A:1024501919714.

[11] Hwang, H.L., Sun, C.Y., Fang, C.S., Chang, S.D., Cheng, C.H., Yang, M.H., Lin, H.H., Tuwan-Mu, H.: Growth and process identification of $\mathrm{CuInS}_{2}$ on $\mathrm{GaP}$ by chemical vapor deposition. Journal of Crystal Growth. 55 (1981) 116-124. https://doi.org/10.1016/00220248(81)90278-5.

[12] Padam, G.K., Rao, S.U.M.: Preparation and characterization of chemically deposited $\mathrm{CuInS}_{2}$ thin films. Solar Energy Materials. 13 (1986) 297-305. https://doi.org/10.1016/0165-1633(86)90004-3.

[13] Bouima, H., Zegadi, A., Satour, F.Z., Zouaoui, A., Hassam, A.: CuIn(Se,S $)_{2}$ thin films synthesis and characterization from a single-bath electrodeposition method. Journal of Electronic Materials. 48 (2019) 4099-4106. https://doi.org/10.1007/s11664-019-07176-9.

[14] Yukawa, T., Kuwabara, K., Koumoto, K.: Electrodeposition of $\mathrm{CuInS}_{2}$ from aqueous solution (II) electrodeposition of CuInS 2 film. Thin Solid Films. 286 (1996) 151-153. https://doi.org/10.1016/S0040-6090(96)08545-8.

[15] Nakamura, S., Yamamoto, A.: Preparation of $\mathrm{CuInS}_{2}$ films with sufficient sulfur content and excellent morphology by one-step electrodeposition. Solar Energy Materials and Solar Cells. 49 (1997) 415-421. https://doi.org/10.1016/S0927-0248(97)00122-0.

[16] Broussillou, C., Andrieux, M., Herbst-Ghysel, M., Jeandin, M., Jaime-Ferrer, J.S., Bodnar, 
S., Morin, E.: Sulfurization of CuIn electrodeposited precursors for $\mathrm{CuInS}_{2}$-based solar cells. Solar Energy Materials and Solar Cells. 95 (2011) S13-S17. https://doi.org/10.1016/j.solmat.2011.01.037.

[17] Bhattacharya, R.N., Cahen, D., Hodes, G.: Electrodeposition of CuInS layers and their photoelectrochemical characterization. Solar Energy Materials. 10 (1984) 41-45. https://doi.org/10.1016/0165-1633(84)90006-6.

[18] Nakamura, S., Yamamoto, A.: Electrodeposited CuInS 2 -based thin-film solar cells. Solar Energy Materials and Solar Cells. 75 (2003) 81-86. https://doi.org/10.1016/S09270248(02)00097-1.

[19] Hodes, G., Engelhard, T., Cahen, D., Kazmerski, L.L., Herrington, C.R.: Electroplated $\mathrm{CuInS}_{2}$ and $\mathrm{CuInSe} 2$ layers: Preparation and physical and photovoltaic characterization. Thin Solid Films. 128 (1985) 93-106. https://doi.org/10.1016/0040-6090(85)90338-4.

[20] Herrero, J., Ortega, J.: Electrodeposition of CuIn alloys for preparing $\mathrm{CuInS}_{2}$ thin films. Solar Energy Materials. 20 (1990) 53-65. https://doi.org/10.1016/0165-1633(90)90017-U.

[21] Yildirim, H., Peksoz A.: Effect of Ga content on the properties of CuGaS precursor thin films produced by electrochemical Co-deposition. Journal of Materials Science: Materials in Electronics. 28 (2017) 6194-6200. https://doi.org/10.1007/s10854-016-6298-z.

[22] Grindle, S.P., Smith, C.W., Mittleman, S.D: Preparation and properties of CuInS 2 thin films produced by exposing sputtered $\mathrm{Cu}$-In films to an $\mathrm{H}_{2} \mathrm{~S}$ atmosphere. Applied Physics Letters. 35 (1979) 24-26. https://doi.org/10.1063/1.90918.

[23] Vadivel, S., Srinivasan, K., Murali, K.R.: Pulse electrodeposited copper indium sulfide 
films. Materials Science in Semiconductor Processing. 16 (2013) 765-770. https://doi.org/10.1016/j.mssp.2012.12.024.

[24] Tauc, J., Grigorovici, R., Vancu, A.: Optical properties and electronic structure of amorphous germanium. Physica Status Solidi (B). 15 (1966) 627-637. https://doi.org/10.1002/pssb.19660150224.

[25] Hodes, G., Engelhard, T., Herrington, C.R., Kazmerski, L.L., Cahen D.: Electrodeposited layers of $\mathrm{CuInS}_{2}, \mathrm{CuIn}_{5} \mathrm{~S}_{8}$ and $\mathrm{CuInSe}_{2}$. Progress in Crystal Growth and Characterization. 10 (1984) 345-351. https://doi.org/10.1016/0146 3535(84)90054-6.

[26] Belgacem, S., Dachraoui, M., Kessler, J., Vedel, J.: Preparation of copper indium disulphide by airless spraying. Thin Solid Films. 167 (1988) 217-222. https://doi.org/10.1016/0040-6090(88)90498-1.

[27] Kim, S.K., Jeong, W.J., Park, G.C., Back, Y.G., Jeong, Y.G., Yoo, Y.T.: Heat-treatment effect of chalcopyrite copper indium disulphide thin film growth. Synthetic Metals. 71 (1995) 1747-1748. https://doi.org/10.1016/0379-6779(94)03034-4.

[28] Pathan, H.M., Lokhande, C.D.: Chemical deposition and characterization of copper indium disulphide thin films. Applied Surface Science. 239 (2004) 11-18. https://doi.org/10.1016/j.apsusc.2004.04.003.

[29] John, T.T., Wilson, K.C., Kumar, P.M.R., Kartha, C.S., Vijayakumar, K.P., Kashiwaba, Y., Abe, T., Yasuhiro, Y:, CuInS 2 films using repeated chemical spray pyrolysis. Physica Status Solidi (A). 202 (2005) 79-84. https://doi.org/10.1002/pssa.200406875.

[30] Guillén, C., Herrero, J.: $\mathrm{CuInS}_{2}$ and $\mathrm{CuGaS}_{2}$ thin films grown by modulated flux 
deposition with various Cu contents. Physica Status Solidi (A). 203 (2006) 2438-2443. https://doi.org/10.1002/pssa.200622132.

[31] Xu, S., Cheng, N., Yin, H., Cao, D., Mi, B.: Electrospray preparation of CuInS 2 films as efficient counter electrode for dye-sensitized solar cells. Chemical Engineering Journal. 397 (2020) 125463.

[32] Rodríguez, C.A., Delgadillo, A., Núñez, J., Cabello-Guzmán, G., Mera, A.C., Delplancke, M.P., Villacampa, B., Carrasco, C.: Effect of supporting electrolyte concentration on onestep electrodeposited $\mathrm{CuInS}_{2}$ films for $\mathrm{ZnS} / \mathrm{CuInS} \mathrm{S}_{2}$ solar cell applications. Journal of Solid State Electrochemistry. 24 (2020) 1405-1414. https://doi.org/10.1016/j.matchemphys.2005.06.018.

[33] Alalousi, M.A., Odeh, A.A., Ibraheam, A.S., Al-Douri, Y.: The effect of Cu/In molar ratio on the analysis and characterization of $\mathrm{CuInS}_{2}$ nanostructures. Emergent Materials. 4 (2021) 413-422. https://doi.org/10.1007/s42247-021-00176-8.

[34] Esmaeili-Zare, M., Behpour, M.: Influence of deposition parameters on surface morphology and application of CuInS2 thin films in solar cell and photocatalysis. International Journal of Hydrogen Energy. 45 (2020) 16169-16182. https://doi.org/10.1016/j.ijhydene.2020.04.106.

[35] Akaki, Y., Nakamura, S., Nomoto, K., Yoshitake, T., Yoshino, K.: Effect of annealing for $\mathrm{CuInS}_{2}$ thin films prepared from Cu-rich ternary compound. Physica Status Solidi (C). 6 (2009) 1030-1033. https://doi.org/10.1002/pssc.200881211.

[36] Sahal, M., Marí, B., Mollar, M.: CuInS 2 thin films obtained by spray pyrolysis for 
photovoltaic applications. Thin Solid Films. 517 (2009) 2202-2204.

https://doi.org/10.1016/j.tsf.2008.10.131.

[37] Rao, P., Kumar, S., Sahoo, N.K.: Growth of copper indium sulphide films by thermal evaporation of mixtures of copper sulphide and indium sulphide powders. Materials Research Bulletin. 48 (2013) 2915-2921.

https://doi.org/10.1016/j.materresbull.2013.04.039.

[38] Suriakarthick, R., Nirmal Kumar, V., Indirajith, R., Shyju, T.S., Gopalakrishnan, R.: Photochemically deposited and post annealed copper indium disulphide thin films. Superlattices and Microstructures. 75 (2014) 667-679. https://doi.org/10.1016/j.spmi.2014.08.012.

[39] Li, L., Li, Q., Wang, H., Yang, X., Tian, H., Xie, J., Wang, W.: Preparation of copper indium sulfide film by electro-deposition method. Rare Metal Materials and Engineering. 44 (2015) 1374-1378. https://doi.org/10.1016/s1875-5372(15)30092-8.

[40] Heidariramsheh, M., Dabbagh, M.M., Mahdavi, S.M., Beitollahi, A.: Morphology and phase- controlled growth of $\mathrm{CuInS}_{2}$ nanoparticles through polyol based heating up synthesis approach. Rare Metal Materials and Engineering. 121 (2020) 105401. 


\section{Figure Captions}

\section{Figure Captions}

\section{Figure 1}

The current-time variation during the electrodeposition of the CIS ternary thin films.

\section{Figure 2}

Cyclic voltammogram of a) In and b) $\mathrm{Cu}-\mathrm{In}-\mathrm{S}$ on ITO substrate.

\section{Figure 3}

SEM image of a) Film 1, b) Film 2 and c) Film 3.

\section{Figure 4}

XRD patterns of a) Film 1, b) Film 2 and c) Film 3

\section{Figure 5}

a) Absorbance spectra of the CIS films, and Tauc plot of b) Film 1, c) Film 2 and d) Film 3. 


\section{Table 1}

Atomic percentages of the produced $\mathrm{Cu}-\mathrm{In}-\mathrm{S}$ precursor thin films. Film stoichiometry is also given.

\begin{tabular}{llllll}
\hline $\begin{array}{l}\text { Deposition } \\
\text { Potential (V) }\end{array}$ & $\mathrm{Cu}(\%)$ & $\mathrm{In}(\%)$ & $\mathrm{S}(\%)$ & $(\mathrm{Cu}+\mathrm{In}) / \mathrm{S}$ & Stoichiometry \\
\hline Film 1 & 3.31 & 59.78 & 36.91 & 1.71 & $\mathrm{CuIn} 18.1 \mathrm{~S}_{11.2}$ \\
Film 2 & 15.82 & 41.45 & 42.73 & 1.34 & $\mathrm{CuIn} 2.62 \mathrm{~S}_{2.70}$ \\
Film 3 & 6.88 & 46.16 & 46.96 & 1.13 & $\mathrm{CuIn} 6.71 \mathrm{~S}_{6.83}$ \\
\hline
\end{tabular}




\section{Table 2}

Crystallite size of the produced CIS materials. Gaussian fit function is used to find out FWHM of each XRD peak.

\begin{tabular}{llllllll}
\hline $\begin{array}{l}\text { XRD peak position } \\
2 \theta\left({ }^{\circ}\right) \rightarrow\end{array}$ & $\begin{array}{l}22.40 \\
(\mathrm{~S} \text { atom })\end{array}$ & $\begin{array}{l}31.8 \\
(\mathrm{CIS})\end{array}$ & $\begin{array}{l}38.6 \\
\left(\mathrm{CIS}_{2}\right)\end{array}$ & $\begin{array}{l}43.4 \\
(\mathrm{~S} \text { atom })\end{array}$ & $\begin{array}{l}45.4 \\
\left(\mathrm{CIS}_{2}\right)\end{array}$ & $\begin{array}{l}69.7 \\
\left(\mathrm{CIS}_{2}\right)\end{array}$ & $\begin{array}{l}\text { Average } \\
\text { crystallite } \\
\text { size }(\mathrm{nm})\end{array}$ \\
\hline $\begin{array}{l}\text { Produced } \\
\text { Film } \downarrow\end{array}$ & & & & & & & \\
\hline Film 1 & 16 & No peak & 27 & 21 & 16 & 22 & 20 \\
Film 2 & 4 & 45 & 7 & No peak & 20 & No peak & 19 \\
Film 3 & 17 & 29 & 19 & No peak & 14 & No peak & 20 \\
\hline
\end{tabular}




\section{Table 3}

The optical and electrical data related with the produced CIS thin films

\begin{tabular}{llll}
\hline $\begin{array}{l}\text { Electrodeposited film } \rightarrow \\
\text { Physical Parameters } \downarrow\end{array}$ & Film 1 & Film 2 & Film 3 \\
\hline Film thickness (nm) & 162 & 140 & 108 \\
Energy band gap (eV) & 1.66 & 1.76 to 2.85 & 1.59 to 2.74 \\
Acceptor density, x10 ${ }^{17}\left(\mathrm{~cm}^{-3}\right)$ & 10.6 & 2.48 & 4.27 \\
Mobility, $\left(\mathrm{cm}^{2} / \mathrm{Vs}\right)$ & 8.68 & 20.9 & 22.2 \\
Resistivity, $(\Omega \mathrm{cm})$ & 6.79 & 8.61 & 6.56 \\
Conductivity, $(1 / \Omega \mathrm{cm})$ & 0.14 & 0.12 & 0.15 \\
Conductivity type & $\mathrm{p}$ & $\mathrm{p}$ & $\mathrm{p}$ \\
\hline
\end{tabular}




\section{Table 4.}

Literature data related with the CIS materials. Production methods listed here are abbreviated such as: single source deposition (SSD), double source deposition (DSD), sputtering and sulfurization (SPS), Airless spraying (AS), thermal evaporation (TE), e-beam evaporation (EBE), electrodeposition (ED), chemical deposition (CD), modulated flux deposition (MFD), spray pyrolysis (SP), electrospinning (ES), pulse galvanostatic deposition (PGD), Photochemical deposition (PCD), heating-up polyol method (HPM)).

\begin{tabular}{|c|c|c|c|c|c|c|c|c|}
\hline $\begin{array}{l}\text { Refe } \\
\text { rences }\end{array}$ & $\begin{array}{l}\text { Produc } \\
\text { tion } \\
\text { method }\end{array}$ & $\begin{array}{l}\text { Crystallite } \\
\text { Size }(n m)\end{array}$ & $\begin{array}{l}\text { Crystalline } \\
\text { phase }\end{array}$ & $\begin{array}{l}\text { Energy } \\
\text { band-gap } \\
\text { interval }(\mathrm{eV})\end{array}$ & $\begin{array}{l}\text { Carrier density } \\
\left(\mathrm{cm}^{-3}\right)\end{array}$ & $\begin{array}{l}\text { Mobility } \\
\left(\mathrm{cm}^{2} / \mathrm{Vs}\right)\end{array}$ & $\begin{array}{l}\text { Resistivity } \\
(\Omega \mathrm{cm})\end{array}$ & $\begin{array}{l}\text { Conductivity } \\
\text { type }\end{array}$ \\
\hline \multirow[b]{2}{*}[3]{} & \multirow{2}{*}{$\begin{array}{l}\text { SSD- } \\
\text { DSD }\end{array}$} & \multirow{2}{*}{-} & \multirow{2}{*}{$\mathrm{CuInS}_{2}$} & \multirow{2}{*}{1.55} & $10^{14}$ to $10^{19}$ & 1 to 10 & 0.1 to 800 & n-type \\
\hline & & & & & $10^{13}$ to $10^{16}$ & $\sim 0.2$ & $0-8$ to 400 & p-type \\
\hline [22] & SPS & $50-100$ & $\mathrm{CuInS}_{2}$ and $\mathrm{In}_{2} \mathrm{~S}_{3}$ & 1.55 & $10^{16}$ & $<0.1,1.0$ & 0.1 to 500 & p-type \\
\hline [26] & AS & - & $\mathrm{CuInS}_{2}$ and $\mathrm{In}_{6} \mathrm{~S}_{7}$ & 1.4 & $1.0-5.0 \times 10^{17}$ & - & - & n-type \\
\hline [27] & EBE & 50 & $\mathrm{InS}$ and $\mathrm{CuInS}_{2}$ & - & $3 \times 10^{20}$ & 0.1 & 0.03 & p-type \\
\hline \multirow{2}{*}[14]{} & \multirow{2}{*}{ ED } & \multirow{2}{*}{$\begin{array}{l}1.9,1.3 \\
\text { and } 0.7\end{array}$} & \multirow{2}{*}{$\begin{array}{l}\mathrm{CuInS}_{2}, \mathrm{CuIn}_{11} \mathrm{~S}_{17} \\
\text { and } \mathrm{In}_{2} \mathrm{O}_{3}\end{array}$} & \multirow{2}{*}{-} & \multirow{2}{*}{-} & \multirow{2}{*}{-} & \multirow{2}{*}{-} & \\
\hline & & & & & & & & n-type \\
\hline [28] & $\mathrm{CD}$ & 4 & $\mathrm{CuInS}_{2}, \mathrm{Cu}_{2} \mathrm{~S}$ & - & - & - & 10 & p-type \\
\hline [29] & SP & $\begin{array}{l}7.85- \\
24.36\end{array}$ & $\mathrm{CuInS}_{2}$ and $\operatorname{In}_{2} \mathrm{~S}_{3}$ & 1.31 to 1.49 & - & - & - & p-type \\
\hline [30] & MFD & $30-55$ & $\mathrm{CuInS}_{2}, \mathrm{Cu}_{\mathrm{x}} \mathrm{S}$ & 1.42 & - & - & - & p-type \\
\hline$[31]$ & SP & 6.2 & $\mathrm{CuInS}_{2}, \mathrm{Cu}_{2} \mathrm{~S}$ & 1.9 & - & - & - & p-type \\
\hline [32] & ED & - & $\mathrm{CuInS}_{2}, \mathrm{In}_{2} \mathrm{O}_{3}$ & 1.40 to 1.45 & - & - & - & - \\
\hline [33] & ES & $23-56$ & $\mathrm{CuInS}_{2}$ & 1.53 to 1.60 & - & - & - & - \\
\hline [34] & ED & - & $\mathrm{CuInS}_{2}, \mathrm{CuS}$ & 1.98 to 2.70 & - & - & - & - \\
\hline$[35]$ & TE & $\begin{array}{l}1500- \\
2000\end{array}$ & $\mathrm{CuInS}_{2}$ and $\mathrm{CuS}$ & - & $1 \times 10^{18}$ to $1 \times 10^{21}$ & 0.1 to 1.0 & 0.1 to 10.0 & p-type \\
\hline [36] & SP & $17-34$ & $\mathrm{CuInS}_{2}$ & 1.53 to 2.16 & - & - & - & - \\
\hline [37] & $\mathrm{TE}$ & $100-200$ & $\begin{array}{l}\mathrm{CuInS}_{2} \text { and } \\
\mathrm{In}_{2} \mathrm{O}_{3}\end{array}$ & 1.5 & - & - & 15 to 288 & p-type \\
\hline [23] & PGD & $15-80$ & $\mathrm{CuInS}_{2}$ & 1.30 to 1.51 & $\begin{array}{l}6.95 \times 10^{18} \text { to } \\
39.98 \times 10^{18}\end{array}$ & $\begin{array}{c}2.45 \text { to } \\
15.54\end{array}$ & 0.1 to 3.67 & p-type \\
\hline [38] & PCD & $12-32$ & $\begin{array}{l}\mathrm{CuInS}_{2}, \mathrm{Cu}_{\mathrm{x}} \mathrm{S} \text { and } \\
\mathrm{In}_{2} \mathrm{~S}_{3}\end{array}$ & 1.6 to 1.9 & $\begin{array}{c}2.5 \times 10^{14} \text { to } \\
1.3 \times 10^{16}\end{array}$ & $\begin{array}{l}0.92 \text { to- } \\
2.42 \times 10^{3}\end{array}$ & $\begin{array}{l}0.54 \text { to } \\
27.29\end{array}$ & p-type \\
\hline [39] & ED & $20-50$ & $\mathrm{CuInS}_{2}$ & 1.5 & - & - & - & - \\
\hline [40] & HPM & $17-20$ & $\begin{array}{l}\mathrm{CuInS}_{2}, \mathrm{CuS}, \\
\mathrm{Cu}_{2} \mathrm{~S}\end{array}$ & 1.46 to 1.57 & $\begin{array}{l}4.2 \times 10^{20} \text { to } \\
8.31 \times 10^{21}\end{array}$ & - & - & p-type \\
\hline $\begin{array}{l}\text { This } \\
\text { work }\end{array}$ & ED & 20 & $\mathrm{~S}$ element, $\mathrm{CuInS}_{2}$ & 1.59 to 2.85 & $\begin{array}{c}2.48 \times 10^{17} \text { to } \\
10.6 \times 10^{17}\end{array}$ & $\begin{array}{c}8.68 \text { to } \\
22.2\end{array}$ & $\begin{array}{c}6.56 \text { to } \\
8.61\end{array}$ & p-type \\
\hline
\end{tabular}


Figures

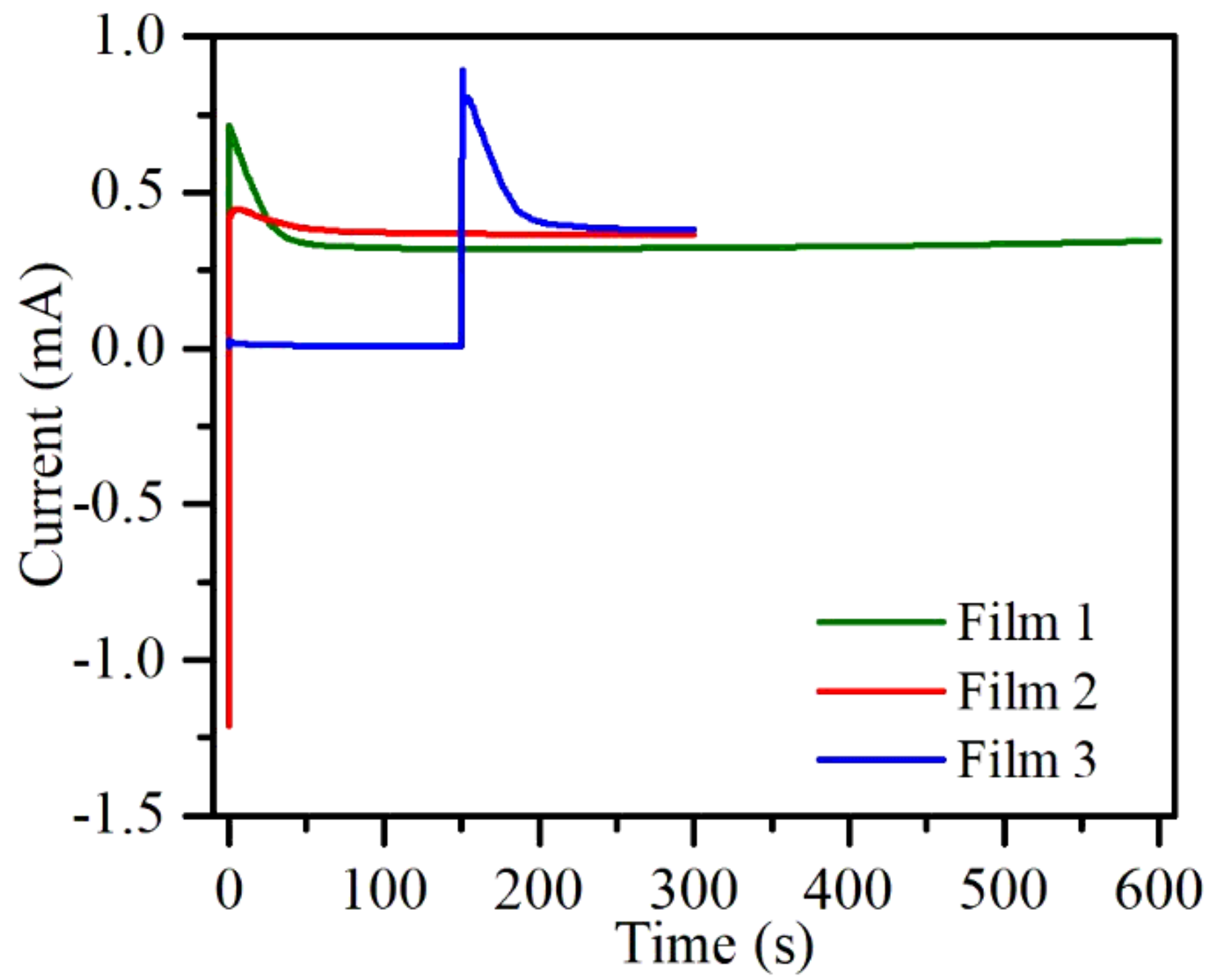

Figure 1

The current-time variation during the electrodeposition of the CIS ternary thin films. 

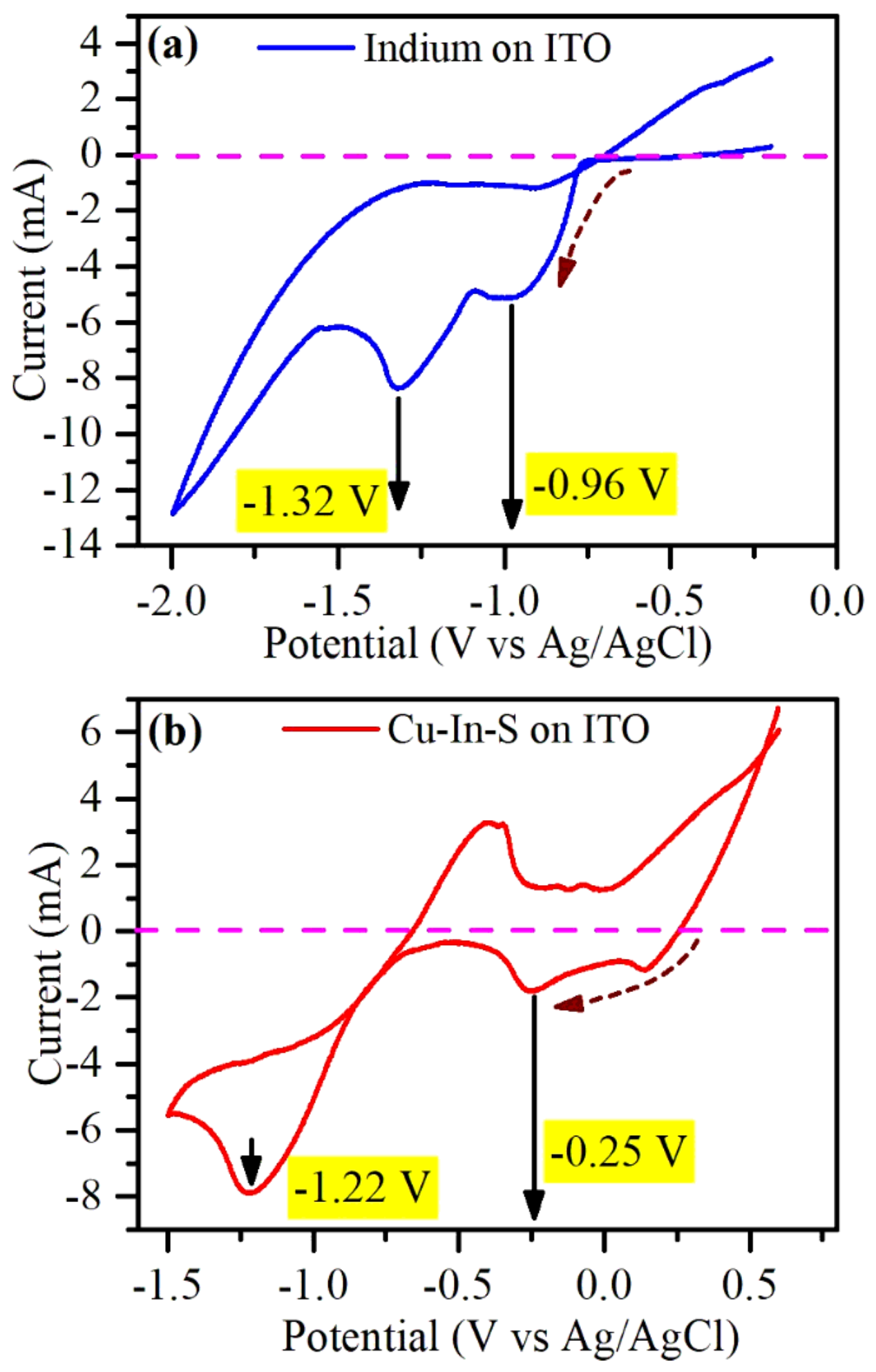

Figure 2

Cyclic voltammogram of a) In and b) Cu-In-S on ITO substrate. 

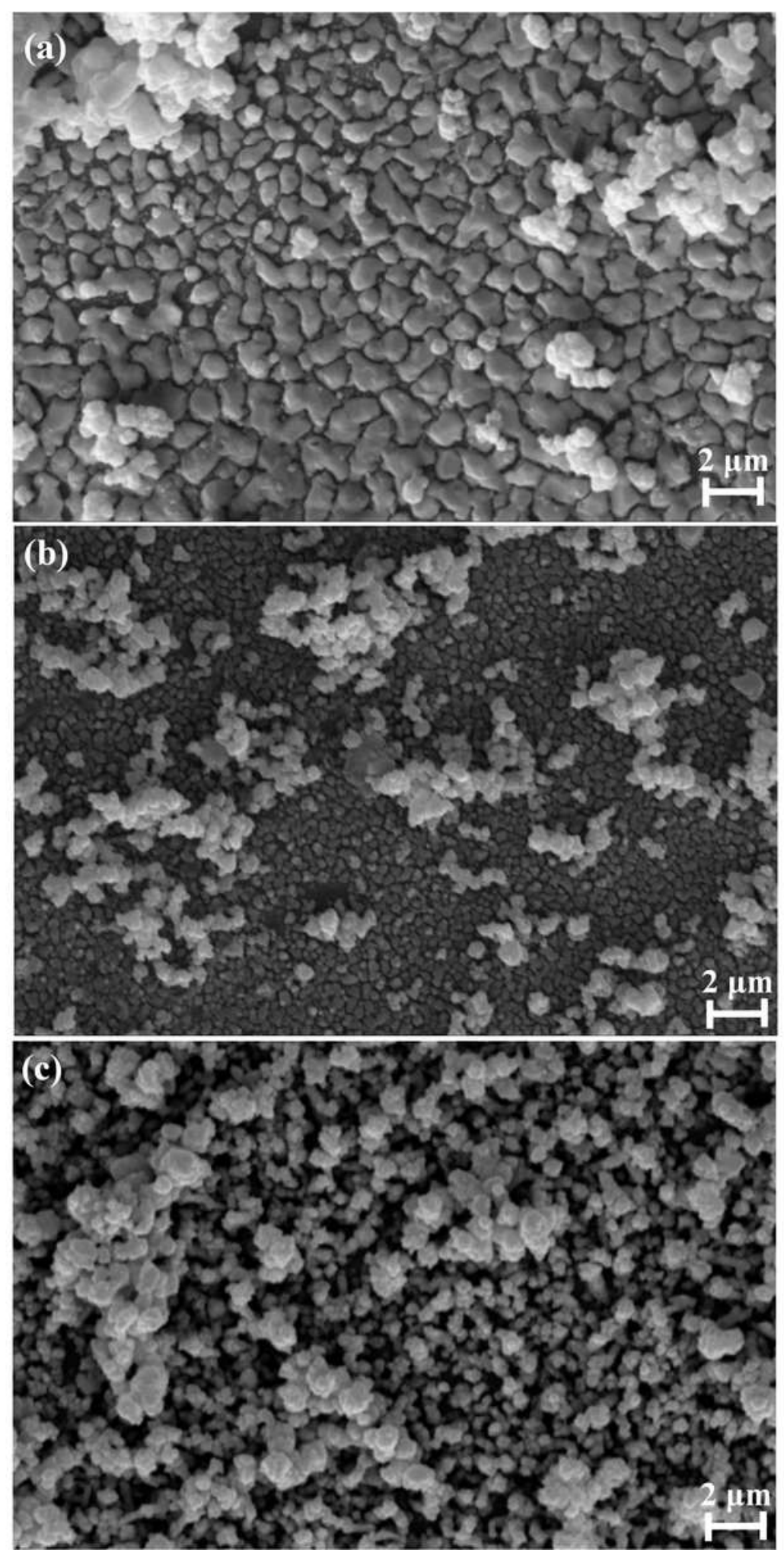

Figure 3

SEM image of a) Film 1, b) Film 2 and c) Film 3. 


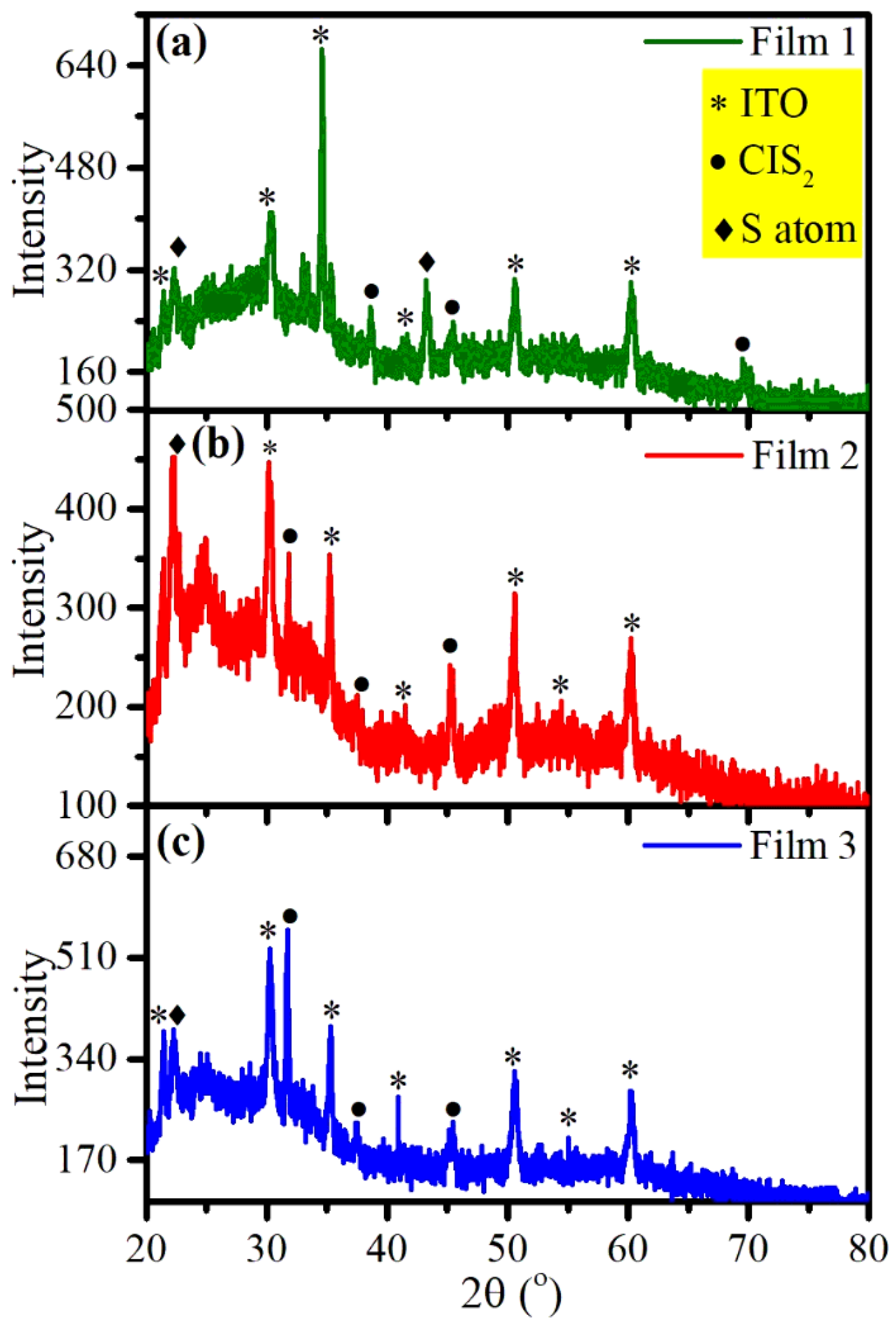

Figure 4

XRD patterns of a) Film 1, b) Film 2 and c) Film 3 

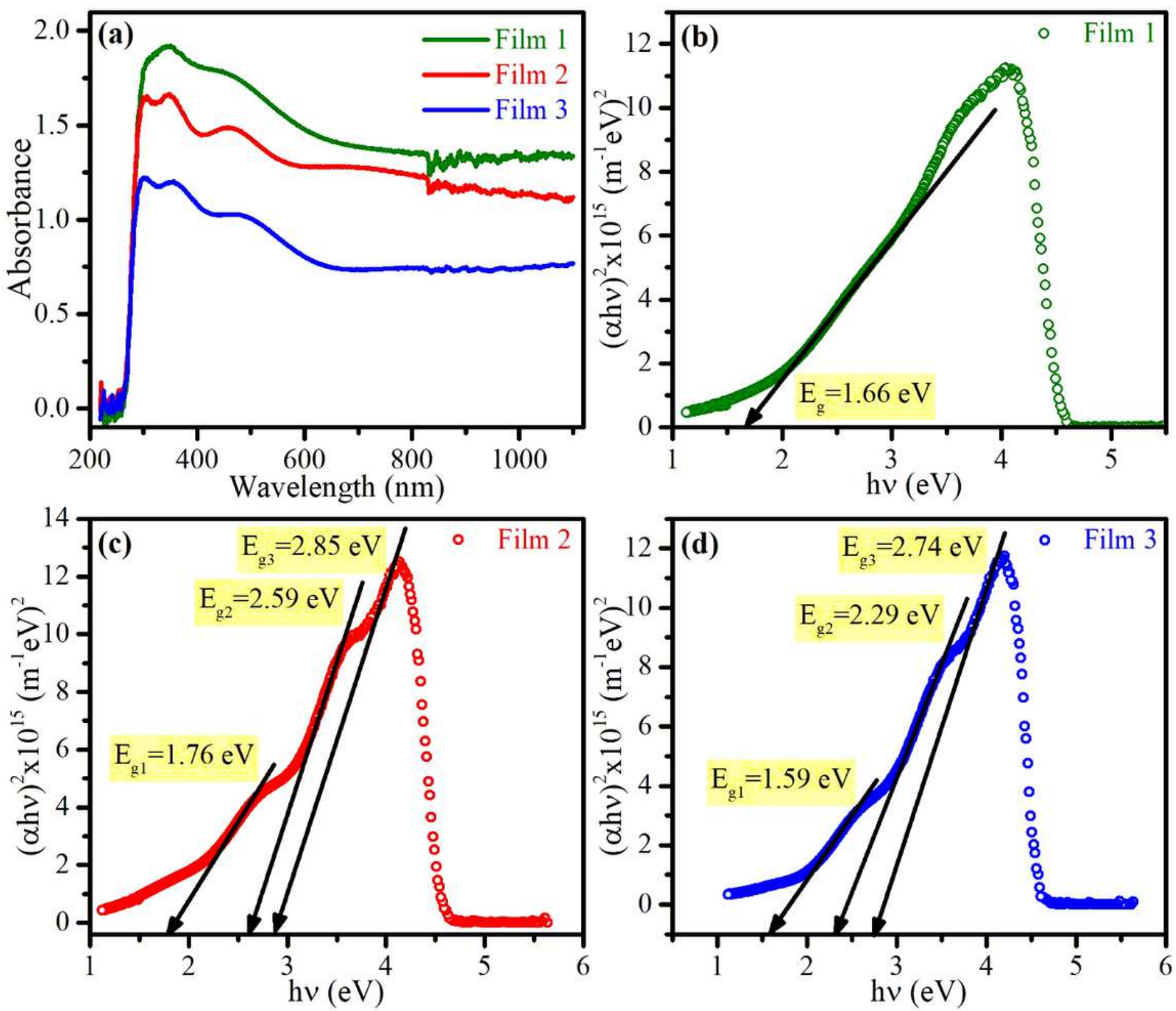

Figure 5

a) Absorbance spectra of the CIS films, and Tauc plot of b) Film 1, c) Film 2 and d) Film 3. 